\title{
Higher prevalence of sexually transmissible co-infections among the human immunodeficiency virus-infected population of South India
}

India has a population of 1.1 billion people - one sixth of the world's population - and is currently home to 2.27 million people with human immunodeficiency virus (HIV) infection (UNAIDS, 2010). The prevalence of HIV in India has been found to be declining in the recent past (UNAIDS, 2010). In the post-highly active antiretroviral therapy era, the life expectancy of HIV patients has significantly improved and the focus is now shifting to the management of co-infections, which have the potential to cause long-term morbidity or mortality (Munshi et al., 2008).

According to earlier reports, hepatitis $B$ virus (HBV) and syphilis were most commonly transmitted during sexual intercourse, but the transmission of hepatitis $\mathrm{C}$ virus (HCV) was rare (Russi et al., 2003; Silverman et al., 2008). It is well known that the presence of genital ulcers (syphilis) significantly increases the transmission of HIV to the sexual partner (Lynn \& Lightman, 2004), and more importantly, chronic liver diseases due to $\mathrm{HBV}$ and $\mathrm{HCV}$ are becoming a leading cause of death among the HIV-infected population worldwide (Lewden et al., 2005; Gupta \& Singh, 2006). It is necessary, therefore, to investigate the prevalence of HBV, HCV and syphilis among the regional HIV-infected population in order to carry out proper remedial action for the local community. Similar data have been published from North India (Gupta \& Singh, 2006), but very little is known about the prevalence of HBV, HCV and syphilis [sexually transmissible infections (STIs)] among the HIV-infected individuals of South India, which directed us to investigate this in our region.

The present study included the patients attending the Integrated Counselling and Testing Centre at Government Theni Medical College Hospital during the period from June 2009 to August 2009. The HIV status of the individuals was ascertained according to National AIDS Control Organization (NACO, 2007) guidelines. Serum samples obtained from the HIVinfected individuals were tested for the presence of hepatitis B surface antigen (HBsAg) (HBsAg ELISA kit; Zhongshan Biotech) and anti-HCV antibody (HCV Microlisa; Mitra). Then, the presence of reagin antibody was evaluated by a nontreponemal rapid plasma reagin card test (Span Diagnostics). The prospective blood donors ( $n=2262$ ) who voluntarily participated in our blood donation camps during the year of 2009 were used as the control group for $\mathrm{HBV}, \mathrm{HCV}$ and syphilis prevalence. The blood donors who were found to be positive for HIV were excluded from the study.

During the study period we enrolled a total of 2436 patients attending our Integrated Counselling and Testing Centre in the study. Among them, 162 (6.7\%) were found to be positive for HIV infection. The infectious status of HBV, $\mathrm{HCV}$ and syphilis among these HIV-positive people was found to be $23(14.2 \%, 1$ in 7$), 7$ $(4.3 \%, 1$ in 23$)$ and $18(11.1 \%, 1$ in 9$)$, respectively (Table 1 ). The overall prevalence of STIs in the HIV population was found to be 22-fold higher compared with the control group [ 29.63 vs $1.33 \%$, respectively; odds ratio (OR) 31.24; $95 \%$ confidence interval (95\% CI) 5.35-182.3] (Table 1).

More specifically, those who were HIV positive were more likely than those who were HIV negative to be infected with syphilis (11.1 vs $0 \%$, respectively) (Table 1). Similarly, those who were HIV positive were more likely than those who were HIV negative to be infected with HBV (14.2 vs $1.1 \%$, respectively; OR 14.88 ; $95 \%$ CI 2.1 -105.8 ) and HCV (4.32 vs $0.22 \%$, respectively; OR 20.48; $95 \%$ CI 0.28 1498.7) (Table 1).

The prevalence of HBV and HCV infections (14.2 and $4.3 \%$, respectively) among the South Indian HIV population were found to be higher compared to reports from North India (5.3 and 2.4\%, respectively) as well as Bangladesh (4.2 and $1.7 \%$, respectively) (Gupta \& Singh, 2006; Munshi et al., 2008). However, the prevalence of STIs in the HIV population of South India was found to be less than the prevalence of STIs in the general population of Ghana (Adjei et al., 2006).

Table 1. Prevalence of STIs among the HIV-infected population of South India

\begin{tabular}{|lccccc|}
\hline Study group & $\begin{array}{c}\text { No. of } \\
\text { samples }\end{array}$ & \multicolumn{3}{c}{ No. of infections (\%) } & $\begin{array}{c}\text { Total no. of } \\
\text { infections (\%) }\end{array}$ \\
\cline { 3 - 5 } & & HBV $^{*}$ & HCV $\dagger$ & Syphilis $\ddagger$ & \\
\hline $\begin{array}{l}\text { HIV infected } \\
\text { Control }\end{array}$ & 162 & $23(14.20)$ & $7(4.32)$ & $18(11.11)$ & $48(29.63)$ \\
$($ HIV & 2262 & $25(1.10)$ & $5(0.22)$ & 0 & $30(1.33)$ \\
negative $)$ & & & & & \\
OR & & 14.88 & 20.48 & Infinity & $(0-\infty)$ \\
$(95 \%$ CI) & & $(2.09-105.77)$ & $(0.28-1498.7)$ & $(5.4-182.3)$ \\
\hline
\end{tabular}

${ }^{\star}$ Detection of HBsAg by ELISA.

$\dagger$ Detection of anti-HCV antibody by ELISA.

$\ddagger$ Detection of reagin antibody by rapid plasma reagin test. 
In conclusion, with the limitation of low sample size, our findings reveal that HIV-infected patients are probably infected with other STIs to a greater extent than those patients not infected with HIV, as we found a 22-fold higher prevalence of STIs among the HIV-infected group than the control group. Additionally, our study demonstrates the higher prevalence of STIs among the HIV population of South India compared to North India. So, the present study strongly indicates the need for routine screening tests for STIs (syphilis, HBV and HCV) among all HIV-infected persons, and for HIV among patients with STIs.

\section{Ramalingam Sekar, Murugesan Amudhan, Moorthy Sivashankar and Manoharan Mythreyee}

Department of Microbiology, Faculty of Medicine, Government Theni Medical College, Tamilnadu Dr M. G. R. Medical University, Theni 625512, India
Correspondence: Manoharan Mythreyee (drmythreyee@gmail.com)

Adjei, A. A., Armah, H. B., Gbagbo, F., Ampofo, W. K., Quaye, I. K., Hesse, I. F. \& Mensah, G. (2006). Prevalence of human immunodeficiency virus, hepatitis $B$ virus, hepatitis $C$ virus and syphilis among prison inmates and officers at Nsawam and Accra, Ghana. J Med Microbiol 55, 593-597.

Gupta, S. \& Singh, S. (2006). Hepatitis B and C virus co-infections in human immunodeficiency virus positive north Indian patients. World $J$ Gastroenterol 12, 6879-6883.

Lewden, C., Salmon, D., Morlat, P., Bevilacqua, S. Jougla, E., Bonnet, F., Heripret, L., Costagliola, D., May, T. \& other authors (2005). Causes of death among human immunodeficiency virus (HIV)-infected adults in the era of potent antiretroviral therapy: emerging role of hepatitis and cancers, persistent role of AIDS. Int J Epidemiol 34, 121-130.

Lynn, W. A. \& Lightman, S. (2004). Syphilis and HIV: a dangerous combination. Lancet Infect Dis 4, 456-466.

Munshi, S. U., Hoque, M. M., Mondol, M. E. A., Jalaluddin, M., Tabassum, S. \& Islam, M. N. (2008). HBV, HCV and syphilis co-infections in human immunodeficiency virus positive
Bangladeshi patients: observation at two reference laboratories. Indian J Med Microbiol 26, 282-283.

NACO (2007). Guidelines on HIV Testing. New Delhi: National AIDS Control Organisation. www.nacoonline.org/About_NACO/Policy_Guidelines/Policies__Guidelines_Table_for_ download

Russi, J. C., Serra, M., Vinoles, J., Perez, M. T., Ruchansky, D., Alonso, G., Sanchez, J. L., Russell, K. L., Montano, S. M. \& other authors (2003). Sexual transmission of hepatitis B virus, hepatitis $C$ virus, and human immunodeficiency virus type 1 infections among male transvestite commercial sex workers in Montevideo,

Uruguay. Am J Trop Med Hyg 68, 716-720.

Silverman, J. G., Decke, M. R., Gupta, J., Dharmadhikari, A., Seage, G. R., III \& Raj, A. (2008). Syphilis and hepatitis B co-infection among HIV-infected, sex-trafficked women and girls, Nepal. Emerg Infect Dis 14, 932934.

UNAIDS (2010). India - Country Progress Report, 2010. Geneva: Joint United Nations Programme on HIV/AIDS. http://data.unaids. org/pub/Report/2010/india_2010_country_ progress_report_en.pdf 